Research Article, Issue 1
Analytical Methods in Environmental Chemistry Journal
AMECJ

\title{
Air Pollution Method: A new method based on ionic liquid passed on mesoporous silica nanoparticles for removal of manganese dust in the workplace air
}

\author{
Parisa Paydara and Ali Faghihi Zarandi a,* \\ ${ }^{a}$ Occupational Health Engineering Department, School of Public Health, Kerman University of Medical Sciences, Kerman, Iran
}

\section{A R T I C L E I N F O:}

Received 15 Dec 2018

Revised form 22 Jan 2019

Accepted 9 Feb 2019

Available online 17 Mar 2019

Keywords:

Manganese dust

Air pollution

Ionic liquid

Mesoporous silica nanoparticles

Solid phase adsorption method

\begin{abstract}
A B S T R A C T
Chronic effect of manganese exposure to humans caused the dysfunction of nervous system. An applied sorbent based on hydrophobic ionic liquid passed on mesoporous silica nanoparticles (IL/MSNPs) was used for adsorption/removal of manganese dust (Mn) from workplace air by solid phase adsorption method (SPAM). In bench scale set up, 5 $\mathrm{mL}$ of standard solution of nitrate and oxide of $\mathrm{Mn}\left(0.2-5 \mathrm{mg} \mathrm{L}^{-1}\right)$ was used for generation of manganese dust in pure air by drying procedure, and then was passed through column of IL/MSNPs by SKC pump with flow rate of $200-500 \mathrm{~mL} \mathrm{~min}{ }^{-1}$ by SKC pump. Moreover, Mn particles were become absorbed/removal from artificial air by IL/ MSNPs at $80{ }^{\circ} \mathrm{C}$. The $\mathrm{Mn}$ particles separated from column of IL/MSNPs by irrigation of nitric acid solution $(2 \mathrm{~mL}$ of $0.3 \mathrm{M})$ before determined by F-AAS/ET-AAS. In optimized conditions, the adsorption capacity of MSNPs and IL/MSNPs for Mn removal from air in batch system (1 Li) was obtained $118.5 \mathrm{mg} \mathrm{g}^{-1}$ and $216.2 \mathrm{mg} \mathrm{g}^{-1}$ respectively. Ultimately, for validation, spike of Mn particles (bag $1 \mathrm{Li}$ ) and ICP was used for dynamic system.
\end{abstract}

\section{Introduction}

Environmental pollution by heavy metals has become a serious problem in the world. The mobilization of heavy metals by man through extraction from ores and processing for different applications has led to the release of these elements into the environment. The problem of heavy metals' pollution is becoming more and more serious with increasing industrialization and disturbance of natural biogeochemical cycles. Unlike organic

\footnotetext{
* Corresponding Author: Ali Faghihi Zarandi

Email: alifaghihi60@yahoo.com

DOI: ttps://doi.org/10.24200/amecj.v2.i01.52
}

substances, heavy metals are essentially nonbiodegradable and therefore accumulate in the environment. This contamination poses a risk to environmental and human health. Some heavy metals are carcinogenic, mutagenic, teratogenic and endocrine disruptors while others cause neurological and behavioral changes especially in children. Thus remediation of heavy metal pollution deserves due attention. Different physical and chemical methods used for this purpose. Heavy metals enter the environment from natural and anthropogenic sources [1]. The most significant natural sources are weathering of minerals, erosion and volcanic activity while anthropogenic 
sources include mining, smelting, electroplating, use of pesticides, and (phosphate) fertilizers as well as bio-solids in agriculture, sludge dumping, industrial discharge, atmospheric deposition etc. [2]. Examples of essential heavy metals are $\mathrm{Fe}, \mathrm{Mn}$, $\mathrm{Cu}, \mathrm{Zn}$, and $\mathrm{Ni}[3,4]$. Non-essential heavy metals are those, which are not needed by living organisms for any physiological and biochemical functions. Examples of nonessential heavy metals are $\mathrm{Cd}$, $\mathrm{Pb}$, $\mathrm{As}, \mathrm{Hg}$, and $\mathrm{Cr}[5,6]$. Blood, urine, and hair are the most accessible tissues in which to measure an exposure or dose; they are sometimes referred to as indicator tissues. Blood and urine concentrations usually reflect recent exposure and correlate best with acute effects. In addition, air might be useful in assessing variations in exposure to metals over the long term. Manganese is one of the essential metals for the body. Also, this metal (Mn) is a required element and a metabolic byproduct of the contrast agent mangafodipirtrisodium (MnDPDP) [7]. In addition, exposure to manganese in the workplace is an occupational health concern, it is known that even at relatively low levels of exposure subtle neurological effects have been observed in workers [8]. Manganese is a transitional metal and can exist in 11 oxidation states, from $3^{-}$to $7^{+}$. The most common valences are $2^{+}, 4^{+}$, and $7^{+}$. The most common valence in biological systems is $2^{+}$; moreover, the valence of $4^{+}$is present as $\mathrm{MnO}_{2}$. $\mathrm{Mn}^{+3}$ is also important in biological systems. Cycling between $\mathrm{Mn}^{+2}$ and $\mathrm{Mn}^{+3}$ may be potentially deleterious to biological systems because it can involve the generation of free radicals. Manganese is an essential element and is a cofactor for a number of enzymatic reactions, particularly those involved in phosphorylation, cholesterol, and fatty acids synthesis. Manganese is present in all living organisms $[9,10]$. The industrial use of manganese has also expanded in recent years as a ferroalloy in the iron industry and as a component of alloys used in welding [11]. Manganese welding is one of the industries exposed to high concentrations of manganese. In this process, manganese metal fumes are produced. According to the NIOSH standard, the exposure limit for this metal is $0.2 \mathrm{mg}$ $\mathrm{m}^{-3}$ [12]. The most common form of manganese toxicity is the result of chronic inhalation of airborne manganese in mines, steel mills, and some chemical industries [10]. Industrial toxicity from inhalation exposure, generally to manganese dioxide in mining or manufacturing, is of two types: The first, manganese pneumonitis, is the result of acute exposure. Men working in plants with high concentrations of manganese dust show an incidence of respiratory disease 30 times greater than normal. Pathologic changes include epithelial necrosis followed by mononuclear proliferation. Mn toxicity has been reported through occupational (e.g. welder) and dietary overexposure and is evidenced primarily in the central nervous system, although lung, cardiac, liver, reproductive, and fetal toxicity have been noted. Mn neurotoxicity results from an accumulation of the metal in brain tissue and results in a progressive disorder of the extrapyramidal system which is similar to Parkinson's disease. In order for Mn to distribute from blood into brain tissue, it must cross either the blood-brain barrier (BBB) or the bloodcerebrospinal fluid barrier (BCB). Brain import, with no evidence of export, would lead to brain $\mathrm{Mn}$ accumulation and neurotoxicity [13,14]. At the present time, the most commonly used methods for assessing workplace airborne metal exposures involve collecting air samples on filters and sending them to a fixed-site laboratory where a variety of analytical methods are used. The National Institute for Occupational Safety and Health (NIOSH) has developed one quantitative field-portable methods to measure airborne lead: NIOSH Method 7300, which uses inductively coupled argon plasma, atomic emission spectroscopy (ICP-AES) [15, 16]. Also, many analytical techniques have been employed for the determination of trace levels of lead in real samples such as, high performance liquid chromatography coupled to inductively coupled plasma mass spectrometry (HPLC-ICP-MS)[17], Inductively coupled plasma mass spectrometry (ICP-MS)[18], inductively coupled plasma atomic emission spectrometry (ICP-AES)[19], flame atomic absorption spectrometry (F-AAS) [20], 
electrothermal atomic absorption spectrometry (ET-AAS)[21], etc. Nowadays, considerable novel method has been introduced in solid-phase extraction (SPE) by applying new nanomaterials with remarkable physicochemical properties that improve the extraction of analytes. Thus, many carbonaceous materials such as activated carbons[22], carbon nanotubes[23], carbon nanohorns [24], carbon nanocones/disks [25] and graphene [26-28] have been applied for analytical preconcentration due to their unique properties, such as reduced particle size, big surface area, high adsorption capacity and good chemical stability [29]. Porous solids are used technically as adsorbents catalysts and catalyst supports owing to their high surface areas. According to the IUPAC definition [30]. Larger pores are present in porous glasses and porous gels which were known as mesoporous materials at the time of the discovery of MCM41. With MCM (Mobil Composition of Matter) 41 the first mesoporous solid was synthesized that showed a regularly ordered pore arrangement and a very narrow pore-size distribution. After the discovery of MCM-41 in 1992. This material has a highly ordered mesoporous hexagonal structure with mesopore diameters varying from 5 to $30 \mathrm{~nm}$ porous materials are divided into three classes: pore-size distributions. Other mesoporous solids microporous $(<2 \mathrm{~nm})$, mesoporous $(2-50 \mathrm{~nm})$ and were synthesized via intercalation of layered mate macroporous $(>50 \mathrm{~nm})$. The pore size and the thickness of the silica walls can be adjusted by varying the heating temperature and time in the reaction solution [31]. Careful investigation of structure of SBA-15 showed that material has certain amount of micropores which connect neighboring mesopores [32,33]. The threshold limit values, permissible exposure limit and occupational exposure limits (TLV/ PEL/OEL) of manganese particles exposure in air determined by international organizations such as, occupational safety and health administration (OSHA, PEL), national institute of occupational safety and health (NIOSH, OEL) and American conference of governmental industrial hygienists (ACGIH, TLV) and were $5 \mathrm{mg} \mathrm{m}^{-3}, 3 \mathrm{mg} \mathrm{m}^{-3}, 5 \mathrm{mg} \mathrm{m}^{-3}$ respectively [34].

So, adsorption/ removal of manganese particles from work place air has more important, due to the high toxicity in human body. In this study, IL/ MSNPs and MSNPs were used for adsorption/ removal of manganese dust $(\mathrm{Mn})$ from workplace air by SPAM. The flow rate, mass / type of sorbent, temperature, and length column are important parameters which have more effected on removal efficiency of MSNPs from workplace and artificial air. The mean of relative standard deviation and preconcentration factor was less than $5 \%$ and 2.5 , respectively.

\section{Experimental procedure}

\subsection{Reagents and instrumental}

Determination of manganese was performed with a spectra GBC flame or electro-thermal atomic absorption spectrometer (Model, Plus 932, Aus). A Mn hollow cathode lamp operating at a current of $5 \mathrm{~mA}$ and a wavelength of $279.5 \mathrm{~nm}$ with a spectral bandwidth of $0.2 \mathrm{~nm}$ was used. The GBC demountable torch of inductively coupled plasma optical emission spectrometer (ICP-OES, Integra $\mathrm{XL}, \mathrm{GBC}$, Aus) with efficient and high performance at reduced gas flow was used for manganese determination. The innovative bayonet mount torch design requires absolutely no re-alignment when replacing individual components. The Integra's standard set of sample introduction components offer unique capabilities that overcome traditional limitations. Optical detector based on dual photomultiplier system (R7154 solar blind tube) with UV detection was used. The plasma gas with $10 \mathrm{~L} \mathrm{~min}^{-1}$ (Ar), auxiliary gas with $0.5 \mathrm{~L} \mathrm{~min}^{-1}(\mathrm{Ar})$, and nebulizer gas with $0.5 \mathrm{~L} \mathrm{~min}^{-1}$ (Ar) were used. The instrumental conditions are shown in Table 1. All reagents with analytical grade were purchased from Merck/Sigma (Darmstadt, Germany). Mn (II) and $\mathrm{Mn}(\mathrm{V})$ were prepared by dissolving appropriate amounts of $\mathrm{Mn}\left(\mathrm{NO}_{3}\right)_{2}, \mathrm{MnO}$, and $\mathrm{KMnO}_{4}$ in DW. The experimental and working standard solutions were prepared daily by diluting the stock solutions with DW. Deionized water 
prepared by water purification system (Millipore, Bedford, MA, USA). Cetylmethyl $\mathrm{NH}_{4} \mathrm{Br}$ (CTAB), $\mathrm{Na}_{2} \mathrm{SiO}_{2}\left(28\right.$ wt $\% \mathrm{SiO}_{2}, 8$ wt $\% \mathrm{Na}_{2} \mathrm{O}, 64$ wt $\%$ $\mathrm{H}_{2} \mathrm{O}$ ), silica gel, $\mathrm{C}_{2} \mathrm{H}_{5} \mathrm{OH}, \mathrm{NaOH}, \mathrm{HCl}$ and $\mathrm{HNO}_{3}$ all were purchased from Merck, Germany. All chemicals such as $\mathrm{HNO}_{3}$ and $\mathrm{NaOH}$, acetone were used as purchased and no further purification was performed.

\subsection{Synthesis}

For synthesis, 3.13 grams of CTAB was added to $70.6 \mathrm{~g}$ of DW and stirred to change clear. First, 7.8 $\mathrm{g}$ of ethanol was added to the surfactant solution and then, $9.7 \mathrm{~g}$ of sodium silicate (28 wt.\% $\mathrm{SiO}_{2}, 5$ wt. $\% \mathrm{Na}_{2} \mathrm{O}, 65$ wt. $\% \mathrm{H}_{2} \mathrm{O}$ ) was mixed to surfactant solution (white suspension). Second, $24.6 \mathrm{~g}$ of sodium carboxyl methyl cellulose solution (12 wt.\%) was added to the suspension and stirred for 3 $\mathrm{h}$ followed by 2 days aging in oven at $70{ }^{\circ} \mathrm{C}$. Then, the precipitate of MSNPS was filtered, washed with deionized water and dried at $100^{\circ} \mathrm{C}$ overnight. The MSNPS was placed in a furnace and calcined with a heating rate of $1 \mathrm{~K} \mathrm{~min}^{-1}$ to $550^{\circ} \mathrm{C}$ and held at this temperature for 6 hours in air. Then, hydrophobic ionic liquid (HIL) of 1-butyl-3-methylimidazolium hexafluorophosphate ([BMIM][PF6]) passed on mesoporous silica nanoparticles (IL/MSNPs). In addition, $0.4 \mathrm{~g}$ of the [BMIM][PF6] with $3 \mathrm{~mL}$ of acetone mixed with $20 \mathrm{mg}$ of MSNPS and after shaking for $3 \mathrm{~min}$, drying up to $75{ }^{\circ} \mathrm{C}$. MSNPS modified with IL was made for further study.

\subsection{Procedure}

The dust of $\mathrm{Mn}$ nitrate and oxide in pure air was

Table 1. Instrumental Conditions for Mn determination by ICP-OES and F-AAS.

\begin{tabular}{lll}
\hline & ICP-OES & F-AAS \\
\hline Element & $\mathrm{Mn}$ & $\mathrm{Mn}$ \\
Wavelength $(\mathrm{nm})$ & 279.48 & 279.5 \\
Lamp current $(\mathrm{mA})$ & -- & 5.0 \\
Slit $(\mathrm{nm})$ & --- & 0.2 \\
Volume spray injection & $0.2 \mu \mathrm{L}$ per min & $2 \mathrm{~mL}$ \\
LOD $\left(\mu \mathrm{g} \mathrm{mL}^{-1}\right)$ & 0.1 & 0.33 \\
Range $^{\text {a }}\left(\mu \mathrm{g} \mathrm{mL}^{-1}\right)$ & $0.5-10$ & $1-4$ \\
Mode & Peak area & Peak area \\
\hline
\end{tabular}

prepared and simulated in beach scale set up by standard solution of Mn (Fig. 1). The Mn nitrate and oxide was generated from $5 \mathrm{~mL}$ of standard solution $\left(0.1-5 \mathrm{mg} \mathrm{L}^{-1}\right)$ after drying up to 110 ${ }^{\circ} \mathrm{C}$ by which was mixed with pure air $(210 \mathrm{~mL}$ of $\mathrm{O}_{2} / \mathrm{L} ; 2.5 \mathrm{~mL}$ of $\mathrm{H}_{2} \mathrm{O} / \mathrm{L}$ ) at $25^{\circ} \mathrm{C}$. This mixture was moved to column which was filled with $20 \mathrm{mg}$ of IL/MSNPs, MSNPs and IL by flow rate of $450 \mathrm{~mL}$ $\mathrm{min}^{-1}$. After adsorption $\mathrm{Mn}$ dusts on sorbent, the column irrigated with $2 \mathrm{~mL}$ of nitric acid $(0.3 \mathrm{M})$ and concentration of $\mathrm{Mn}$ in final solution determined by F-AAS and ICP-OES. Note, the IL paste on MSNPs caused to increase the adsorption capacity of Mn dust from air as compared to MSNPs. By increasing temperature from $38-70^{\circ} \mathrm{C}$, the removal efficiency was almost increased. The removal efficiency of proposed method was calculated by ratio of concentration of $\mathrm{Mn}$ in bulk of pilot to concentration of $\mathrm{Mn}$ which was determined by ICP-OES/F-AAS. For validation of methodology, different concentration of $\mathrm{Mn}$ was generated by pilot and spike to air samples dust. The recovery and adsorption capacity $\left(\mathrm{mg} \mathrm{g}^{-1}\right)$ was calculated at $50^{\circ} \mathrm{C}$ as follows: $\mathrm{C}_{\mathrm{s}}$ and $\mathrm{C}_{\mathrm{b}}\left(\mu \mathrm{g} \mathrm{mL}^{-1}\right.$ or $\left.\mathrm{mg} \mathrm{L}^{-1}\right)$ are concentration in sample and blank solution respectively. $\mathrm{C}_{\mathrm{i}}$ and $\mathrm{C}_{\mathrm{f}}$ are the initial and final concentrations of $\mathrm{MnO} / \mathrm{Mn}\left(\mathrm{NO}_{3}\right)_{2}$. In addition, the $\mathrm{V}(\mathrm{mL})$ and $m(\mathrm{mg})$ were the volume solution and mass of sorbent, respectively. The recovery was calculated by using Equation 2.

Eq. 1 Adsorption capacity $\left(\mathrm{mg} \mathrm{g}^{-1}\right)=\left[\left(C_{i}-C_{p}\right){ }_{v}\right] / m$

Eq. $2 \quad$ Recovey $\%=\frac{\left.C_{i}-C_{f}\right)}{C} \times 100$

\subsection{Characterizations}

X-ray diffraction (XRD) patterns were reported by a GBC diffractometer with Be-filtered $\mathrm{Cu} \mathrm{K \alpha}$ radiation (1.54 $\AA$ ) operating at $36.5 \mathrm{kV}$ and 30 $\mathrm{mA}$. Diffraction data was recorded between 1 and $10^{\circ} 2 \theta$ with a resolution of $0.01^{\circ} 2 \theta$ with the scan rate of $0.52 \theta \mathrm{min}^{-1}$. Scanning electron micrograph was recorded using a Zeiss DSM 962 (Zeiss, Oberkochen, Germany). The sample was deposited 


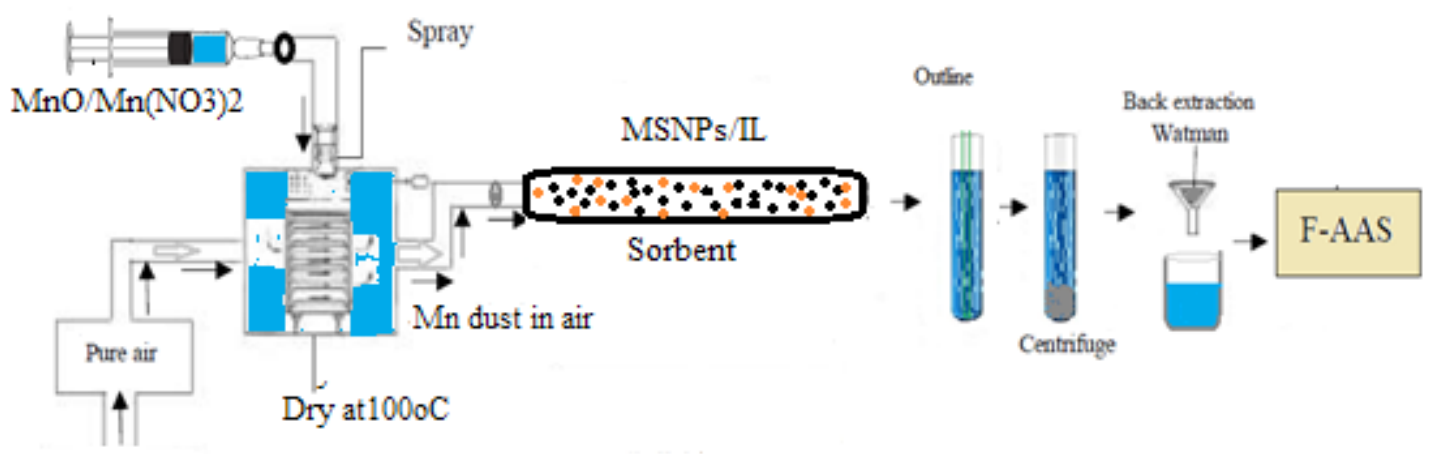

Fig. 1. Beach scale set up with standard solution of Mn by SPAM.

on a sample holder with an adhesive carbon foil and sputtered with gold. Adsorption/desorption of Nitrogen was carried out at $77 \mathrm{~K}$ using a BELSORP-mini porosimeter. Prior to analysis the samples were outgassed in-vacuo for 5 hours at 280 ${ }^{\circ} \mathrm{C}$ until a stable vacuum of $0.12 \mathrm{~Pa}$ was reached. The pore size distribution was calculated from the desorption branches of isotherms using the standard BJH procedure and also with geometrical (pressure independent) method. Transmission electron microscopy (TEM) was performed on a LEO Zeiss 912 AB. The morphology of MSNPs was examined using scanning electron microscopy (SEM) by Phillips, PW3710, Netherland Company. Sample were dispersed in ethanol and sonicated for 30 minutes and deposited on a copper grid. The synthesis was prepared as the weight of calcined solid per grams of $\mathrm{SiO}_{2}$ in the initial mixture. The elemental analyzer (CHNS/O, PerkinElmer, 2400
Series II) was used for determination of elemental composition of samples. CHN instrument perform elemental ratio calculations of $\mathrm{H} / \mathrm{C}, \mathrm{N} / \mathrm{C}, \mathrm{S} / \mathrm{C}$ or $\mathrm{C} / \mathrm{N}$.

\section{Results and discussion}

\subsection{SEM and TEM imaging}

As shown in Figure 2, IL/MSNPs have a highly porous morphology and the mesoporous silica particles are in nanometer range (40-60 $\mathrm{nm})$. Moreover, IL passed on MSNPs did not led to bulky silica nanoparticles. TEM image also illustrates pore structure of IL/MSNPs was shown in figure 5. Based on TEM, the mesoporous are clearly visible in the silica nanoparticles and particle size of the samples is in nanometer range as those observed in SEM image.
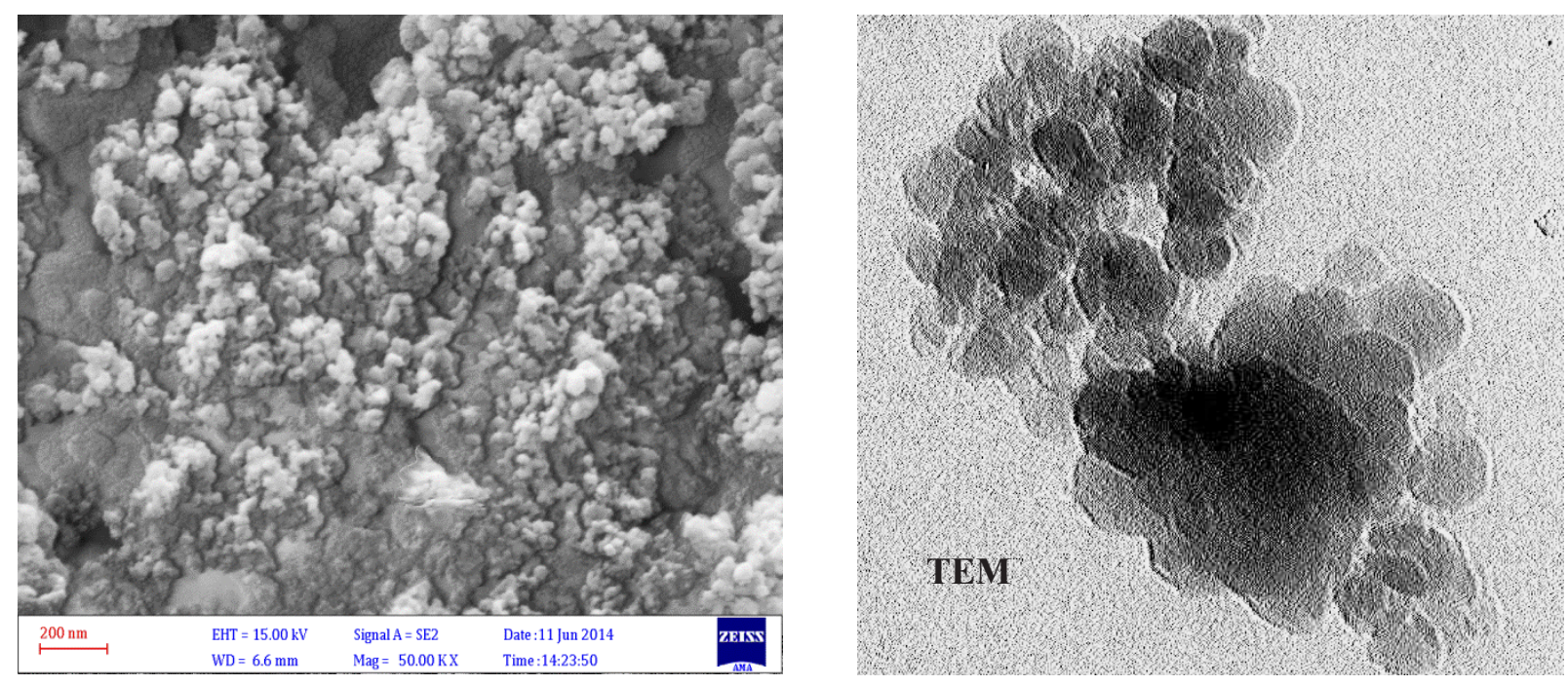

Fig. 2. TEM and SEM of IL/MSNPs sorbent 


\subsection{Effect of the Mass of MSNPS/IL}

The removal efficiency of Mn particles from air with IL/MSNPs was examined between 5-50 mg. The results showed, $15 \mathrm{mg}$ of sorbent had more efficiency for Mn dust removal from air (more than 95\%). So, $20 \mathrm{mg}$ of IL/MSNPs was selected as the optimum amounts of adsorbent in gas phase by proposed method. Based on results, $20 \mathrm{mg}$ [BMIM] [PF6] and [EMIM][PF6] and [HMIM][PF6] can be removal Mn dust from air up to $38.4 \%, 26 \%$, and $32 \%$, respectively. So, [BMIM][PF6] was used as IL in this research.

\subsection{Removal efficiency and Adsorption capacity}

In this study, the parameters effected on removal efficiency and adsorption capacity were studied by different temperatures $\left(20-100^{\circ} \mathrm{C}\right)$, flow rates $\left(50,100,200,400\right.$ and $\left.600 \mathrm{~mL} \mathrm{~min}^{-1}\right)$ and initial concentrations of $0.1-5 \mathrm{mg} \mathrm{L}^{-1}(\mathrm{ppm})$. Finally, the adsorption capacity of $216.2 \mathrm{mg} \mathrm{g}^{-1}, 118.5 \mathrm{mg} \mathrm{g}^{-1}$ and $67.4 \mathrm{mg} \mathrm{g}^{-1}$ was obtained for Mn dust removal from air with $20 \mathrm{mg}$ IL/MSNPs, MSNPs and IL, respectively. Different ILs such as [BMIM][PF6] and [EMIM][ PF6] and [HMIM][PF6] passed on MSNPs and effect of temperature on Mn adsorption process was investigated. The results showed, increasing of temperature between $38-70{ }^{\circ} \mathrm{C}$, decreased the viscosity of ILs and caused to efficient removal of Mn dust from air, so, $50^{\circ} \mathrm{C}$ was selected as optimum temperature. Initial concentrations of
0.01-1 $\mathrm{mg} \mathrm{L}^{-1}(\mathrm{ppm})$ of Mn dust were examined by proposed procedure. It seems that, the initial concentrations of $\mathrm{Mn}$ dusts depended on mass of sorbent/IL and adsorption capacity. When the adsorption capacity of IL/MSNPs was increased, the more concentration of Mn can be used. As a 20 $\mathrm{mg}$ of sorbent and adsorption capacity of $216 \mathrm{mg}$ $\mathrm{g}^{-1}$, the maximum concentration of $4.32 \mathrm{mg}$ of $\mathrm{Mn}$ was obtained.

\subsection{Effect of air flow rate}

By SPAM procedure, the effect of flow rate for Mn dust removal from air was studied for 30 samples. The effect of different flow rates for $20 \mathrm{mg}$ IL/ MSNPs, MSNPs, and IL between 50 to $800 \mathrm{~mL}$ $\mathrm{min}^{-1}$ was tested at room temperature and $50^{\circ} \mathrm{C}$. The flow rate was measured in output of solid phase by a rotameter. The removal efficiency and adsorption capacity of IL/MSNPs, MSNPs and IL for Mn dust

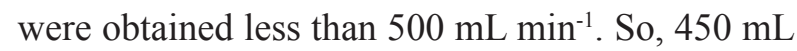
$\mathrm{min}^{-1}$ was selected as optimum flow rate with IL/ MSNPs phase for removal of Mn dust from air (Fig. 4).

\subsection{Method Validation and Column Condition}

The back extraction of Mn from IL/MSNPs was occurred with the minimal concentration of different acid solution. By SPAM method, the different acid solution was used for back extraction $\mathrm{Mn}$ ions from column. Reducing $\mathrm{pH}$, leads to dissociation and

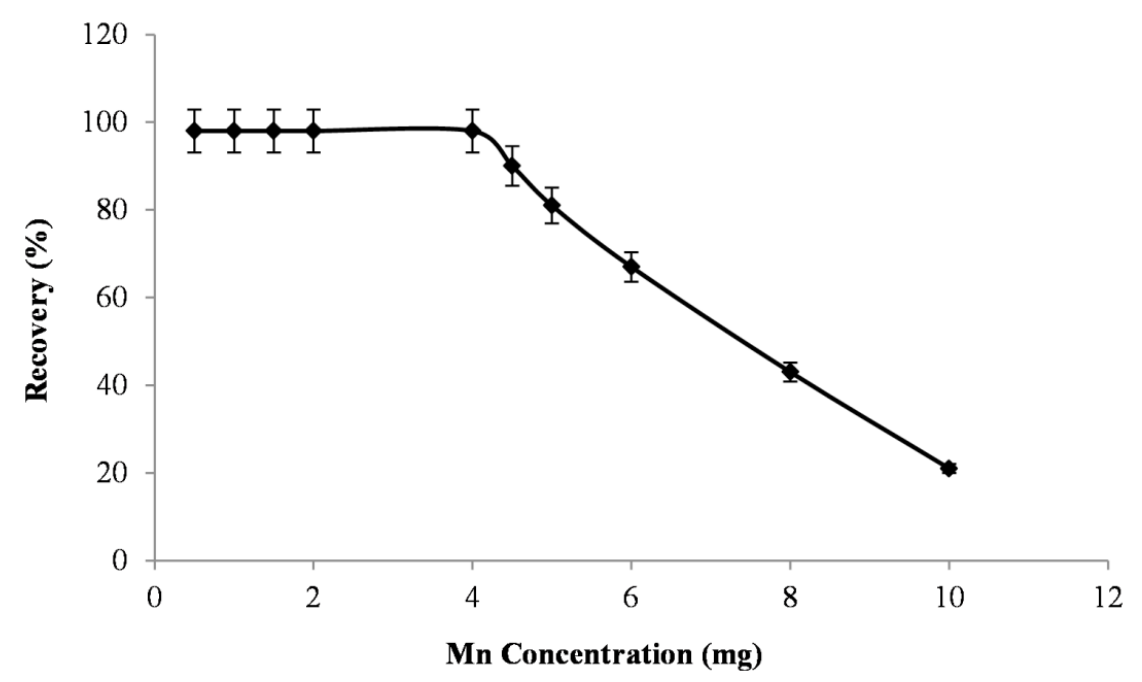

Fig. 2. The effect of concentration for manganese removal from air. 


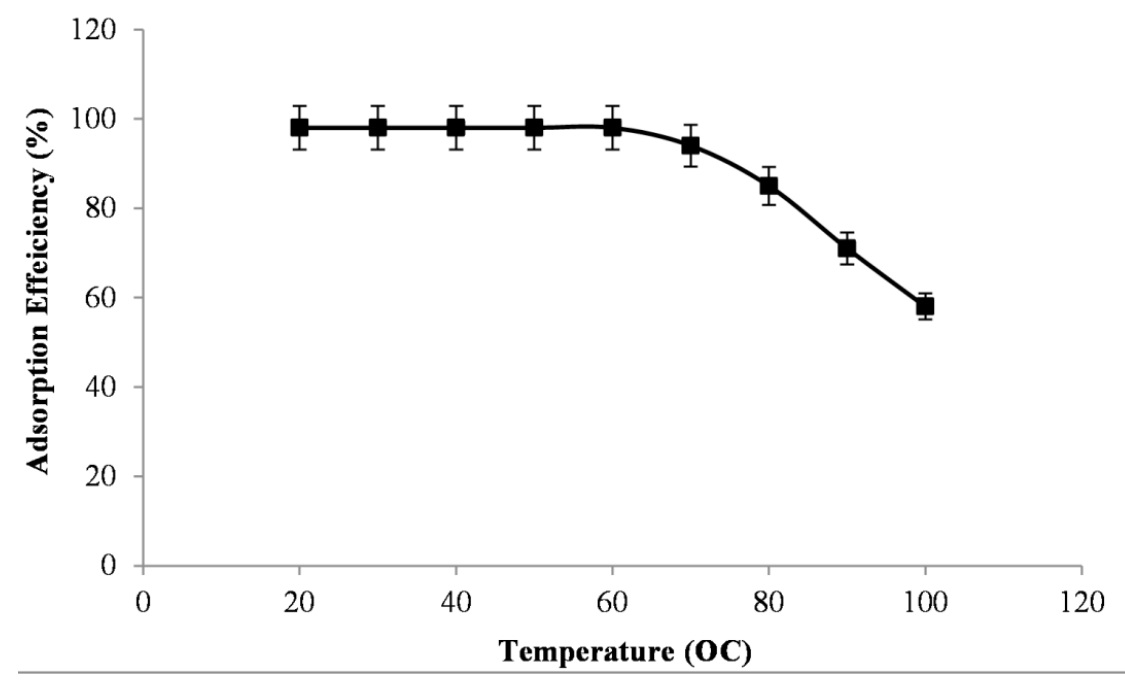

Fig. 3. The effect of temperature for manganese removal from air.

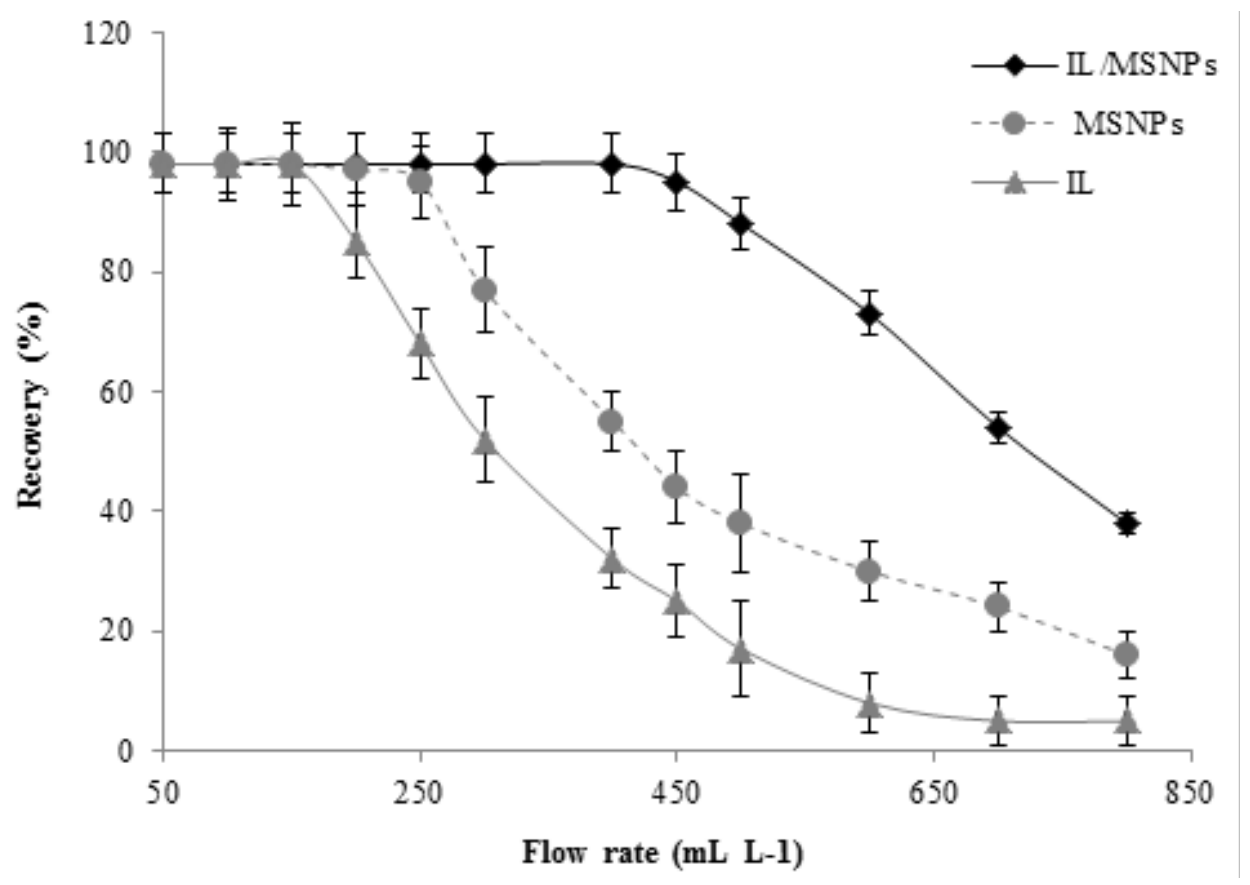

Fig. 4. Effect of flow rate on recovery percentage.

releasing of Mn (II) ions from IL/MSNPs, MSNPs and IL into acid phase. In order to determine the type and amount of mineral acidic solution for lead desorption from IL/MSNPs, different mineral acids such as $\mathrm{HCl}, \mathrm{HNO}_{3}$ and $\mathrm{H}_{2} \mathrm{SO}_{4}\left(0.1-1 \mathrm{~mol} \mathrm{~L}^{-1}\right)$ were studied by proposed procedure. The results showed, the $0.3 \mathrm{~mol} \mathrm{~L}^{-1}$ of $\mathrm{HNO}_{3}$ solution was selected as a quantitatively acid solution for back extraction of Mn(II) from IL/MSNPs. By experimental design, the interaction between manganese dust in air and IL/MSNPs as a sorbent was evaluated when the pilot set up correctly. In this method, the IL/ MSNPs, MSNPs and IL was used for removal of for $\mathrm{Mn}$ dust ( $\mathrm{MnO}$ and $\mathrm{Mn}\left(\mathrm{NO}_{3}\right)_{2}$ ) from air by SPAM. For calculating of accuracy and precision of dynamic system, the initial Mn concentration in bench scale set up (bulk container) was determined by F-AAS and compared to proposed method by sorbents. By proposed method, the Mn dust with different concentration from $0.1-1 \mathrm{mg} \mathrm{L}^{-1}$ was generated and passed through dynamic system with $450 \mathrm{~mL} \mathrm{~min}^{-1}$ and removal from air by 20 
mg of IL/MSNPs. The different concentration of standard of $\mathrm{MnO}$ and $\mathrm{Mn}\left(\mathrm{NO}_{3}\right)_{2}$ in air bags and bulk container was determined by F-AAS before used by proposed method. Since standard reference material (SRM) for Mn nitrate and oxide in air dust are not currently available, the spiked of Mn concentration in air which was generated by bench set up (0.1-5 $\left.\mathrm{mg} \mathrm{L}^{-1}, 450 \mathrm{~mL} \mathrm{~min}^{-1}\right)$ were prepared to demonstrate the reliability of the method by IL/MSNPs, MSNPs and IL sorbents (Table 2, 3). For determination of manganese concentration in lower and upper linear range, the sample was preconcentration and dilution up to 2.5 and 12.5, respectively. At optimized set up, more than $98 \%$ of Mn oxide and nitrate in air dust were removed by IL/MSNPs at $50^{\circ} \mathrm{C}$. The high recovery of spiked samples is satisfactorily reasonable and was confirmed using addition method, which indicates the capability of SPAM method for removal of Mn dust from air. After irrigation of column with 2 $\mathrm{mL}$ of nitric acid $(0.3 \mathrm{M}, \mathrm{pH}<4)$, the $\mathrm{Mn}$ ions was back extracted from IL/MSNPs as a solid phase and $\mathrm{Mn}$ concentration determined by F-AAS. The validation of methodology was confirmed using power instrumental analyzer ICP (Table 4).

\section{Conclusions}

In this research, the adsorption/removal of pollutant Mn dust from air was achieved based on IL/MSNPs and MSNPs by SPAM. The results showed, the unique, efficient, and applied procedure which was used for removal of Mn particles dust from workplace and artificial air. For increasing of removal recovery, Mn concentration, amount of IL/MSNPs, temperature from 20-100 and flow rate were studied and optimized. The capacity adsorption, recovery, removal efficiency of sorbents was investigated and compared together by F-AAS and ICP-OES. Based on the results, the adsorption capacity IL/MSNPs were more than MSNPs for nitrate/oxide of Mn dust from workplace air. In addition, the efficiency of adsorption for $\mathrm{MnO}$

Table 2. Method validation for IL/MSNPs by spike of Mn oxide in dust air with F-AAS (mg L-1)

\begin{tabular}{|c|c|c|c|c|}
\hline $\begin{array}{l}\text { Bench } \\
\text { (Conc.) }\end{array}$ & $\begin{array}{l}\text { Bulk Bench } \\
\text { (Conc.) }\end{array}$ & $\begin{array}{l}\text { Added to bench } \\
\text { (Conc.) }\end{array}$ & Found $^{\mathrm{a}}$ & Recovery (\%) \\
\hline${ }^{\mathrm{b}} 0.2$ & $0.16 \pm 0.02$ & 0.2 & $0 . .31 \pm 0.03$ & 96.8 \\
\hline${ }^{\mathrm{b}} 0.3$ & $0.28 \pm 0.02$ & 0.3 & $0.53 \pm 0.05$ & 94.6 \\
\hline b 0.5 & $0.44 \pm 0.04$ & 0.5 & $0.87 \pm 0.07$ & 98.9 \\
\hline 1.0 & $0.95 \pm 0.08$ & 1.0 & $1.85 \pm 0.11$ & 97.3 \\
\hline c3.0 & $2.78 \pm 0.16$ & 3.0 & $5.62 \pm 0.27$ & 101.2 \\
\hline $\mathrm{c} 5.0$ & $4.69 \pm \cdot, 24$ & 5.0 & $9.02 \pm \cdot, 48$ & 96.1 \\
\hline
\end{tabular}

Table 3. Method validation for IL/MSNPs by spike of Mn nitrate in dust air with F-AAS (mg L ${ }^{-1}$ )

\begin{tabular}{|c|c|c|c|c|}
\hline $\begin{array}{l}\text { Bench } \\
\text { (Conc.) }\end{array}$ & $\begin{array}{l}\text { Bulk Bench } \\
\text { (Conc.) }\end{array}$ & $\begin{array}{l}\text { Added to bench } \\
\text { (Conc.) }\end{array}$ & Found $^{\mathrm{a}}$ & Recovery (\%) \\
\hline${ }^{\mathrm{b}} 0.4$ & $0.35 \pm 0.02$ & 0.4 & $0 . .67 \pm 0.04$ & 95.7 \\
\hline${ }^{\mathrm{b}} 0.6$ & $0.52 \pm 0.05$ & 0.6 & $0.99 \pm 0.10$ & 95.2 \\
\hline 1.0 & $0.92 \pm 0.09$ & 1.0 & $1.88 \pm 0.12$ & 102.3 \\
\hline 2.0 & $1.86 \pm 0.13$ & 2.0 & $3.65 \pm 0.18$ & 98.1 \\
\hline$c^{3} 3.0$ & $2.65 \pm 0.17$ & 3.0 & $5.18 \pm 0.28$ & 97.7 \\
\hline c5.0 & $4.51 \pm 0.25$ & 5.0 & $8.94 \pm 0.48$ & 99.1 \\
\hline
\end{tabular}

${ }^{\mathrm{a}}$ Mean of three determinations \pm confidence interval $(\mathrm{P}=0.95, \mathrm{n}=5)$

${ }^{\mathrm{b}}$ (Preconcentration Factor $=2.5$, Injection volume $=2 \mathrm{~mL}, 450 \mathrm{~mL} \mathrm{~min}^{-1}$ air flow rate, Peak Area, $20 \mathrm{mg}, \mathrm{T}=50^{\circ} \mathrm{C}, \mathrm{pH}<4$ )

${ }^{\mathrm{c}}$ (Dilution Factor=2.5, Injection volume $=12.5 \mathrm{~mL}, 450 \mathrm{~mL} \mathrm{~min}^{-1}$ air flow rate, Peak Area, $20 \mathrm{mg}, \mathrm{T}=50^{\circ} \mathrm{C}, \mathrm{pH}<4$ ) 
Table 4. Comparing of different sorbents for removal of Mn oxide by ICP-OES/F-AAS (mg L-1)

\begin{tabular}{lllllll}
\hline Sample* & $\begin{array}{l}\text { Bulk Bench } \\
\text { (Conc.) }\end{array}$ & $\begin{array}{l}\text { Added } \\
\text { (Conc.) }\end{array}$ & $\begin{array}{l}\text { F-AAS } \\
\text { (Conc.) }\end{array}$ & $\begin{array}{l}\text { ICP-OES } \\
\text { (Conc.) }\end{array}$ & $\begin{array}{l}\text { FAAS } \\
\text { Recovery (\%) }\end{array}$ & $\begin{array}{l}\text { ICP-OES } \\
\text { Recovery (\%) }\end{array}$ \\
\hline IL & 1.0 & ---- & $0.26 \pm 0.02$ & $0.29 \pm 0.02$ & 26 & 29 \\
& & 1.0 & $0.54 \pm 0.03$ & $0.56 \pm 0.04$ & 28 & 27 \\
& & 2.0 & $0.83 \pm 0.04$ & $0.88 \pm 0.05$ & 28.5 & 29.5 \\
IL/MSNPs & 1.0 & ----- & $0.98 \pm 0.05$ & $0.99 \pm 0.06$ & 98 & 99 \\
& & 1.0 & $1.99 \pm 0.09$ & $1.97 \pm 0.10$ & 101 & 98 \\
MSNPs & 2.0 & $2.96 \pm 0.15$ & $2.95 \pm 0.16$ & 99 & 98 \\
& 1.0 & ----- & $0.52 \pm 0.03$ & $0.56 \pm 0.02$ & 52 & 56 \\
& & 1.0 & $1.03 \pm 0.05$ & $1.11 \pm 0.06$ & 51 & 55 \\
\end{tabular}

${ }^{\mathrm{a}}$ Mean of three determinations \pm confidence interval $(\mathrm{P}=0.95, \mathrm{n}=5)$

* (450 $\mathrm{mL} \mathrm{min}^{-1}$ air flow rate, Peak Area, $\left.20 \mathrm{mg}, \mathrm{T}=50^{\circ} \mathrm{C}, \mathrm{pH}<4\right)$

and $\mathrm{Mn}\left(\mathrm{NO}_{3}\right)_{2}$ was increased at more than 38-70 ${ }^{\circ} \mathrm{C}$ and decreased more than $90{ }^{\circ} \mathrm{C}$. Finally, the results showed that the flow rate is important factor in dynamic system, and optimized flow rate was achieved less than $450 \mathrm{~mL} \mathrm{~min}^{-1}$. The method had good ability for removal of Mn dust from air.

\section{Acknowledgments}

We are thankful to Research Institute of Petroleum Industry (RIPI) and Iranian Petroleum Industry Health Research Institute (IPIHRI).

\section{References}

[1] R. A. Wuana, F. E. Okieimen, Heavy metals in contaminated soils: a review of sources, chemistry, risks and best available strategies for remediation. Isrn Ecol., (2011).

[2] H. Ali, E. Khan, M. A. Sajad, Phytoremediation of heavy metals, concepts and applications, Chemosphere, 91(2013) 869-881.

[3] E. R. Donati, Heavy Metals in the Environment: Microorganisms and Bioremediation, CRC Press, 2018.

[4] J.N. Bhakta, Metal toxicity in microorganism. Handbook of research on inventive bioremediation techniques. IGI Global, PA, pp.1-23, 2017.

[5] W. Mertz, The essential trace elements. Sci., 213(1981) 1332-1338.

[6] S. Jena, S. K. Dey, Heavy metals, Am. J. Environ. Sci., 1(2017) 48-60.

[7] P. Chen, J. Bornhorst, M. Aschner, Manganese metabolism in humans, Front Biosci., 23(2018)
1655-1679.

[8] M. G. Baker, C. D. Simpson, B. Stover, L. Sheppard, H. Checkoway, B. A. Racette, N. S. Seixas, Blood manganese as an exposure biomarker, state of the evidence, J. Occup. environ. Hgy ., 11 (2014) 210217.

[9] J. L. Aschner, M. Aschner, Nutritional aspects of manganese homeostasis, Mol. Aspects Med ., 26(2005) 353-362.

[10] B. L.Carson, Toxicology biological monitoring of metals in humans, CRC Press, 2018.

[11] N. H. Mthombeni, S. Mbakop1and, M. S. Onyango, In adsorptive removal of manganese from industrial and mining wastewater, proceedings of pustainable research and innovation conference, (2016) 36-45.

[12] J. Morton, H. Beattie, E. Leese, K. Jones, The usefulness of biological monitoring in determining manganese exposure in the workplace, Occup. Environ. Med., 75(2018).

[13] W. Horst, The physiology of manganese toxicity, In Manganese in soils and plants, Springer: Com. Chem., (1988) 175-188.

[14] M. Gawlik, M. B. Gawlik, I. Smaga, M. Filip, Manganese neurotoxicity and protective effects of resveratrol and quercetin in preclinical research, Pharma. Rep ., 69(2017) 322-330.

[15] P. M. Eller, M. E. Cassinelli, NIOSH manual of analytical methods, Diane Publishing, 94(1994).

[16] J. E. C. Lerner, M. L. Elordi, M. A. Orte, D. Giuliani, de los Angeles Gutierrez, M.; Sanchez, E.; Sambeth, J. E.; Porta, A. A., Exposure and risk analysis to particulate matter, metals, and polycyclic aromatic hydrocarbon at different workplaces in Argentina, 
Environ. Sci. Pollut. Res., (2018) 1-10.

[17] N. Solovyev, M. Vinceti, P. Grill, J. Mandrioli, B. Michalke, Redox speciation of iron, manganese, and copper in cerebrospinal fluid by strong cation exchange chromatography-sector field inductively coupled plasma mass spectrometry, Anal. Chim. Acta., 973(2017) 25-33.

[18] J. Griboff, D. A. Wunderlin, M. V. Monferran, Metals, As and Se determination by inductively coupled plasma-mass spectrometry (ICP-MS) in edible fish collected from three eutrophic reservoirs. Their consumption represents a risk for human health, Microchem. J., 130(2017) 236-244.

[19] A. A. Alqadami, M. Naushad, M. A. Abdalla, M. R. Khan, Z. A. Alothman, S. M. Wabaidur, A. A. Ghfar, Determination of heavy metals in skinwhitening cosmetics using microwave digestion and inductively coupled plasma atomic emission spectrometry, IET nanobiotechnol., 11(2017) 597603.

[20] M. Baghdadi, F. Shemirani, H. R. L. Z. Zhad, Determination of cobalt in high-salinity reverse osmosis concentrates using flame atomic absorption spectrometry after cold-induced aggregation microextraction, Anal. Methods, 8(2016) 19081913.

[21] A. Prkić, A. Jurić, J. Giljanović, N. Politeo, V. Sokol, P. Bošković, M. Brkljača, A. Stipišić, C. Fernandez, T. Vukušić, Monitoring content of cadmium, calcium, copper, iron, lead, magnesium and manganese in tea leaves by electrothermal and flame atomizer atomic absorption spectrometry, Open. Chem., 15 (2017) 200-207.

[22] J. LIU, X.f. HU, Gray System Study on the Influence of Particle Size Distribution on Adsorption Performance of Activated Carbon, Bull. Chin. Ceram. Soc ., 4(2010) 015.

[23] G. G. Wildgoose, C. E. Banks, R. G. Compton, Metal nanoparticles and related materials supported on carbon nanotubes: methods and applications, Small, 2 (2006) 182-193.

[24] M. Roldán-Pijuán, R. Lucena, S. Cárdenas, M. Valcárcel, Micro-solid phase extraction based on oxidized single-walled carbon nanohorns immobilized on a stir borosilicate disk: application to the preconcentration of the endocrine disruptor benzophenone, Microchem. J, 115(2014) 87-94.

[25] J. M. Jiménez-Soto, S. Cárdenas, M. Valcárcel,
Evaluation of carbon nanocones/disks as sorbent material for solid-phase extraction, J. Chromatogr ., 30( 2009) 5626-5633.

[26] I. E. M. Carpio, J. D. Mangadlao, H. N. Nguyen, R. C. Advincula, D. F. Rodrigues, Graphene oxide functionalized with ethylenediamine triacetic acid for heavy metal adsorption and anti-microbial applications, Carbon, 77(2014) 289-301.

[27] A. Miller, P. L. Drake, P. Hintz, M. Habjan, Characterizing exposures to airborne metals and nanoparticle emissions in a refinery,. Annal.Occup. Hyg., 54 (2010) 504-513.

[28] Y. Mao, J. Yuan, J. Zhong, Density functional calculation of transition metal adatom adsorption on graphene, J. Phys. Condens. Matter., 20(2008) 115209.

[29] D. R. Dreyer, S. Park, C. W. Bielawski, R. S. Ruoff, The chemistry of graphene oxide, Chem. Soc. Rev., 39(2010) 228-240.

[30] M. Oregui-Bengoechea, N. Miletić, W. Hao,; F. Björnerbäck, M. H. Rosnes,;S. J. Garitaonandia, N. Hedin, P. L. Arias, T. Barth, High-Performance Magnetic Activated Carbon from Solid Waste from Lignin Conversion Processes. 2. Their Use as NiMo Catalyst Supports for Lignin Conversion, ACS Sustain. Chem. Eng., 5(2017) 11226-11237.

[31] D. Zhao, J. Feng, Q. Huo, N. Melosh, G. H. Fredrickson, B. F. Chmelka, G. D. Stucky, Triblock copolymer syntheses of mesoporous silica with periodic 50 to 300 angstrom pores, sci., 279(1998) 548-552.

[32] P. Yang, D. Zhao, D. I. Margolese, B. F. Chmelka, G. D. Stucky, Generalized syntheses of large-pore mesoporous metal oxides with semicrystalline frameworks, Nature, 396(1998) 152.

[33] R. Guillet-Nicolas, R. Ahmad, K. A. Cychosz, F. Kleitz, M. Thommes, Insights into the pore structure of KIT-6 and SBA-15 ordered mesoporous silicarecent advances by combining physical adsorption with mercury porosimetry, New J. Chem., 40(2016) 4351-4360.

[34] K.M. Choi, H.-C. An, Characterization and exposure measurement for indium oxide nanofibers generated as byproducts in the LED manufacturing environment. J. Occup. Environ. Hyg., 13(2016) 23-30. 